\title{
Estimating and Applying Fish and Invertebrate Density and Production Enhancement from Seagrass, Salt Marsh Edge, and Oyster Reef Nursery Habitats in the Gulf of Mexico
}

\author{
Philine S. E. zu Ermgassen ${ }^{1}$ (D) $\cdot$ Bryan DeAngelis $^{2}$ • Jonathan R. Gair ${ }^{3} \cdot$ Sophus zu Ermgassen $^{4} \cdot$ Ronald Baker $^{5}$. \\ Andre Daniels ${ }^{6} \cdot$ Timothy C. MacDonald $^{7} \cdot$ Kara Meckley $^{8} \cdot$ Sean Powers ${ }^{5} \cdot$ Marta Ribera $^{9} \cdot$ Lawrence P. Rozas $^{10}$. \\ Jonathan H. Grabowski ${ }^{11}$
}

Received: 13 July 2020 / Revised: 2 March 2021 / Accepted: 24 March 2021 / Published online: 20 April 2021

(C) The Author(s) 2021

\begin{abstract}
Seagrasses, oyster reefs, and salt marshes are critical coastal habitats that support high densities of juvenile fish and invertebrates. Yet which species are enhanced through these nursery habitats, and to what degree, remains largely unquantified. Densities of young-of-year fish and invertebrates in seagrasses, oyster reefs, and salt marsh edges as well as in paired adjacent unstructured habitats of the northern Gulf of Mexico were compiled. Species consistently found at higher densities in the structured habitats were identified, and species-specific growth and mortality models were applied to derive production enhancement estimates arising from this enhanced density. Enhancement levels for fish and invertebrate production were similar for seagrass (1370 [SD 317] $\mathrm{g} \mathrm{m}^{-2} \mathrm{y}^{-1}$ for 25 enhanced species) and salt marsh edge habitats (1222 [SD 190] $\mathrm{g} \mathrm{m}^{-2} \mathrm{y}^{-1}, 25$ spp.), whereas oyster reefs produced $\sim 650$ [SD 114] $\mathrm{g} \mathrm{m}^{-2} \mathrm{y}^{-1}$ (20 spp). This difference was partly due to lower densities of juvenile blue crab (Callinectes sapidus) on oyster reefs, although only oyster reefs enhanced commercially valuable stone crabs (Menippe spp.). The production estimates were applied to Galveston Bay, Texas, and Pensacola Bay, Florida, for species known to recruit consistently in those embayments. These case studies illustrated variability in production enhancement by coastal habitats within the northern Gulf of Mexico. Quantitative estimates of production enhancement within specific embayments can be used to quantify the role of essential fish habitat, inform management decisions, and communicate the value of habitat protection and restoration.
\end{abstract}

Keywords Ecosystem services $\cdot$ Restoration $\cdot$ Conservation $\cdot$ Essential fish habitat $($ EFH) $\cdot$ Pensacola Bay $\cdot$ Galveston Bay

$\underline{\text { Lawrence P. Rozas is a retired personnel at NOAA Fisheries Service. }}$

Communicated by Melisa C. Wong

Philine S. E. zu Ermgassen

Philine.zuermgassen@ cantab.net

Bryan DeAngelis

bdeangelis@TNC.ORG

Jonathan R. Gair

J.Gair@ed.ac.uk

Sophus zu Ermgassen

sz251@kent.ac.uk

Ronald Baker

rbaker@disl.org

Andre Daniels

andre_daniels@usgs.gov

\author{
Timothy C. MacDonald \\ Tim.MacDonald@MyFWC.com \\ Kara Meckley \\ kara.meckley@noaa.gov \\ Sean Powers \\ spowers@disl.org \\ Marta Ribera \\ marta.ribera@TNC.ORG
}

Lawrence P. Rozas

lprsunset@gmail.com

Jonathan H. Grabowski

j.grabowski@northeastern.edu

Extended author information available on the last page of the article 


\section{Introduction}

Coastal habitats in temperate and tropical estuaries provide a diverse array of valuable ecosystem services that humans rely upon. For instance, seagrass beds, oyster reefs, salt marshes, coral reefs, and mangroves collectively stabilize shoreline erosion, prevent flooding, remove excess nitrogen from estuaries, and provide nursery and adult habitat for nekton (fish and mobile invertebrates) (Barbier et al. 2011; Spalding et al. 2014; Hutchinson et al. 2015; Smyth et al. 2015; zu Ermgassen et al. this issue). Each habitat provides a physically complex structure shown to increase survival and growth of recently settled fish and invertebrates, and densities of juvenile nekton associated with these habitats are often high (Heck et al. 2003; Hollweg et al. 2020a; Lefcheck et al. 2019). Where such structured nursery habitats have been lost, populations of species that are associated with the habitat as juveniles may be habitat limited (Folpp et al. 2020). In such cases, preservation or restoration of habitat can support increased numbers of juveniles and ultimately enhance fish and invertebrate production through increased population sizes (Peterson et al. 2003; Sundblad et al. 2014; Folpp et al. 2020).

Relative to historical baselines, coastal habitats have been highly degraded or lost entirely in numerous locations (Lotze et al. 2006; Orth et al. 2006; zu Ermgassen et al. 2012). When these habitats are degraded, the ecosystem functions and the associated services that they previously provided may also decrease or be lost entirely (Peterson and Lipcius 2003). The widespread degradation of coastal habitats has occurred throughout much of the Gulf of Mexico (Kennish 2001; Waycott et al. 2009; zu Ermgassen et al. 2012). For example, marsh edge in parts of Galveston Bay was reduced by $70 \%$ between 1982 and 1995 due primarily to sea level rise and shoreline erosion (Rozas et al. 2007), and marsh area declined by $20 \%$ bay-wide since the 1950 s (White et al. 1993, cited in Levin and Stunz 2005). Sea level rise and shoreline erosion are accelerating under climate change, and further losses are predicted (Yoskowitz et al. 2017). Seagrass beds in Galveston Bay declined by $>60 \%$ from the 1950 s to 1980 s, with only about 210 ha of seagrass now remaining (Pulich 2007; Pulich and White 1991). Additionally, oyster biomass in Galveston Bay declined by $93 \%$ across the twentieth century (zu Ermgassen et al. 2012). In Pensacola Bay, seagrasses declined by over 50\% from 1960 to 2003 (Lewis et al. 2008), with slight increases since (Yarbro and Carlson 2016); salt marshes declined by an estimated 53\% from approximately 1940 to 2014 (Lewis et al. 2016, p.104); and oyster reefs are reported to have declined by 50-70\% from 1987 to 2015 (Lewis et al. 2016). The degradation and loss of these habitats here and elsewhere has often resulted in their replacement by unstructured soft sediments.

Efforts to quantify ecosystem function and service delivery can be used to inform management, conservation, and restoration of these threatened coastal ecosystems (Grabowski et al. 2012; Failler et al. 2015; Cebrian et al. 2020; Lai et al. 2020). For example, the essential fish habitat $(\mathrm{EFH})$ provisions of the Magnuson-Stevens Fishery Conservation and Management Act (Magnuson-Stevens Act) specify that the fishery management councils utilize the best available science to describe and identify EFH for federally managed species to protect it to the extent practicable. The highest level of EFH information is level 4: production rates by habitat type, yet level 4 EFH information is largely unavailable for most commercially harvested species. This lack of level $4 \mathrm{EFH}$ information is currently limiting the inclusion of habitat parameters in stock assessments and in ecosystembased management plans (Levin and Stunz 2005; Grüss et al. 2017). Furthermore, area-based estimates of ecosystem service delivery may inform decision-making related to protected area management and habitat restoration, by allowing the per unit area contribution of protected or restored habitat to be quantified.

Here, we provide quantitative estimates of the fish and mobile invertebrate production enhancement arising from the nursery function of seagrass, oyster reef, and salt marsh edge habitats for the northern Gulf of Mexico. Production enhancement refers to the annual biomass which can be attributed to the growth of those additional individuals that recruit to the system as a result of the presence of structured habitat. We build on an established method for estimating production enhancement (zu Ermgassen et al. 2016), introducing an improved method for estimation of the likely density enhancement of these habitats in the northern Gulf of Mexico, by factoring in the standard error of reported densities as opposed to giving them all equal weight and by giving each bay or estuary equal weighting when deriving the Gulf of Mexicowide values. We illustrate how these estimates can be applied to individual locations to better understand the contribution of existing habitat and the potential fish and invertebrate production benefits of habitat restoration. In addition, by applying our approach to case study locations in the Gulf of Mexico with bay-specific fish species information, we highlight geographic variation in the functional values of coastal habitats (Ziegler et al. 2021). The approach described is easily transferable to other regions where sufficient juvenile fish and invertebrate density data exist across paired unstructured and threatened structured habitats.

\section{Methods}

\section{Underlying Assumptions}

As with earlier applications of this method (Peterson et al. 2003; zu Ermgassen et al. 2016), an underlying assumption is that the dramatic declines in structured coastal habitats 
throughout the northern Gulf of Mexico have likely limited the recruitment of species associated with structure as juveniles. These habitats provide physically complex structure that increases the survival and growth of recently settled fish and invertebrates, explaining why nekton densities are consistently higher on them relative to adjacent unstructured mud and sand bottom (Thayer et al. 1978). As such, the presence or addition of structured habitat supports the addition of recruits to the population over and above the recruitment that occurs in the absence of that habitat, as observed in Eurasian perch (Perca flavescens) in the Baltic Sea (Sundblad et al. 2014), in Sparidae on rocky reefs around Australia (Folpp et al. 2020), and as previously demonstrated across numerous species associated with eastern oyster reefs in the USA (Peterson et al. 2003, zu Ermgassen et al. 2016). We recognize that biotic factors including shoot density and percent cover as well as abiotic conditions such as temperature and salinity may also affect the degree to which a location supports recruitment of juveniles. The paired structured-nonstructured densities used to estimate enhancement include samples that span a broad range of seascape contexts and environmental conditions across the northern Gulf of Mexico. As a result, our estimates of mean production enhancement from the structured habitats include variability in production driven by site-specific biotic and abiotic factors that regulate nekton production in these systems. While there is not currently sufficient data to model the effects of these biotic and abiotic factors within our framework, the enhancement estimates we present reflect the net result of the presence of the structured habitats and can therefore be accurately described as enhancement due to the structured habitats. We refer to recruitment in an ecological as opposed to fisheries context, meaning that the study focused on the enhancement of young-of-year (YOY) individuals and the nursery function of the structured habitats in question and not the recruitment of individuals into a harvestable stage.

\section{Data Collection and Handling}

We conducted a comprehensive literature search for studies reporting fish and mobile invertebrate abundance on seagrass, oyster reef, and salt marsh edge habitats. Studies were included in the database when they met the following criteria: (1) At least one of the structured habitats was sampled as well as adjacent unstructured control habitat, (2) gear designed to capture YOY and resident individuals was used, and (3) reporting methods allowed for the density of individual species to be determined. Included gear types were limited to drop and throw nets, lift nets, habitat trays, benthic push trawls, and epibenthic sleds (Table S1). While habitat trays are likely to sample benthic species efficiently, they are not designed to sample species which swim away rather than burrow in response to disturbance. Incidental catches of swimming species such as pinfish (Lagodon rhomboides) were therefore removed from habitat tray data. Infaunal species, and species with a maximum size $<4 \mathrm{~cm}$, were not included. The gear types represented in the dataset sampled all age classes for a small number of primarily benthic resident species with a small body size and a strong affinity for structure, such as gobies, blennies, and toadfish. In these cases, year 0.5 density was back calculated using a size-dependent mortality model (Lorenzen 2000), assuming that the density observed included all age classes. The species to which this method was applied were identified by expert knowledge (Table S2).

Salt marsh edge was defined as the first $1 \mathrm{~m}$ of open water and $2 \mathrm{~m}$ of vegetation along the shoreline of natural Spartina marshes. Seagrass habitats included primarily Halodule- and Thalassia-dominated beds. While Ruppia was present in some seagrass habitats included in our study, Ruppia-dominated habitats were excluded. Data were also included from the South Florida Seagrass Fish and Invertebrate Assessment Network (FIAN). In this case, data were summarized to include samples with $>=70 \%$ seagrass cover as seagrass habitat and samples with $<5 \%$ seagrass cover in the category "unstructured control." Only natural habitats were included in the seagrass and salt marsh edge datasets, whereas oyster reef data included both restored and natural habitats. This variation in data acceptance was applied because few natural oyster reefs remain and have been sampled, and when they do exist, they often have been degraded by harvesting (zu Ermgassen et al. 2012). Grabowski et al. (2005) found that many species recruited to restored oyster reefs within weeks to months after restoration occurred, though complete reassembly is likely a much longer process. Studies comparing salt marsh restoration efforts to natural habitat have demonstrated that recovery is often slower (McSkimming et al. 2016; Baumann et al. 2018; Hollweg et al. 2020b).

Data for each habitat were summarized and handled independently. All data were summarized into spatially and temporally independent samples to avoid pseudoreplication in the resulting dataset. We defined independent sampling units as samples that were collected in different bays or estuaries (Figure 1) or in different seasons (defined as Spring = March, April, and May; Summer = June, July, and August; Fall $=$ September, October, and November; and Winter $=$ December, January and February).

\section{Identifying Enhanced Species}

As in zu Ermgassen et al. (2016), species were deemed to be enhanced by the structured habitat if they fulfilled the following criteria: (1) The species was more abundant within the structured habitat than in the control in at least half of the independent sampling events, (2) it was represented by data from at least two geographically distinct 


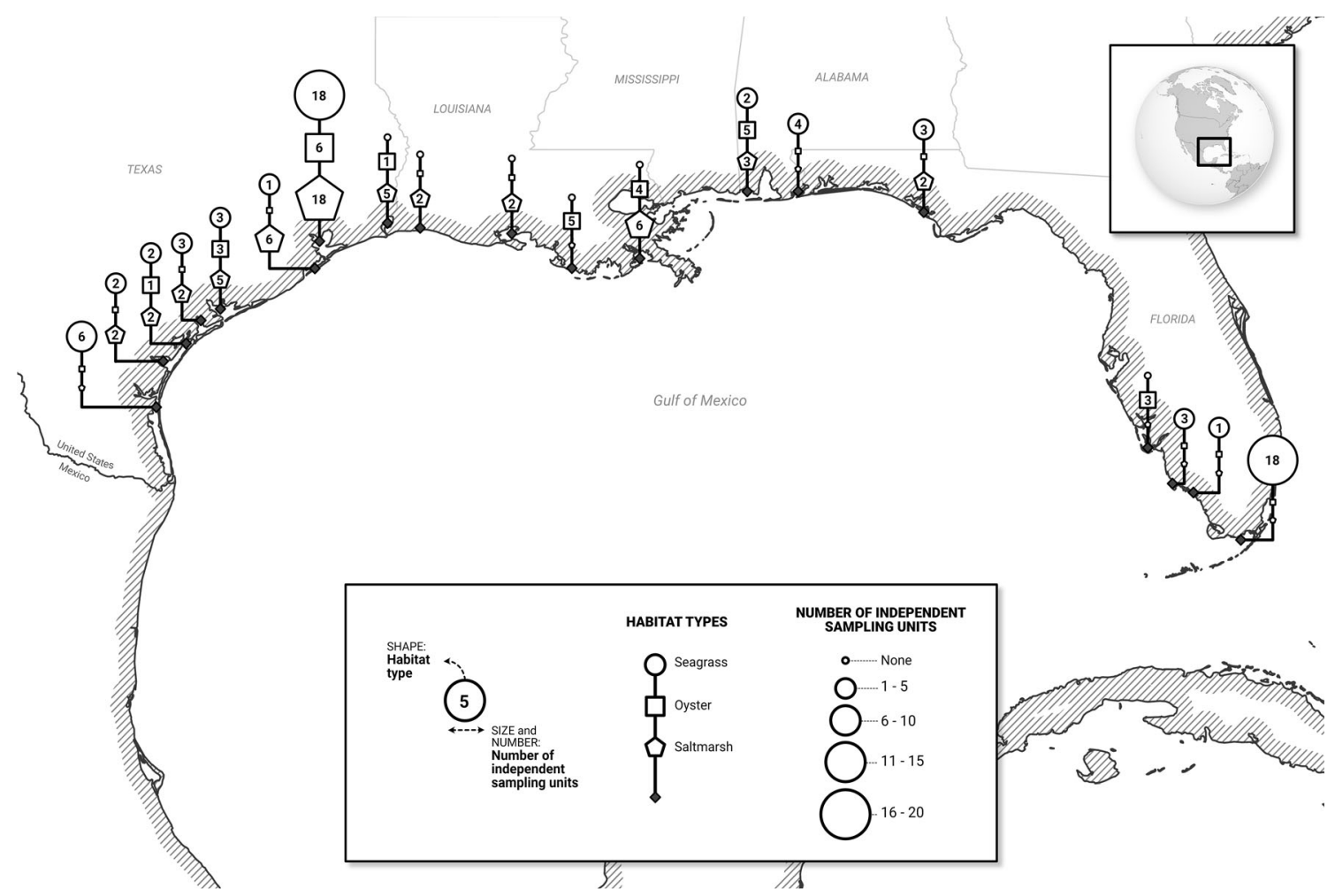

Fig. 1 Map illustrating the location of studies included in the dataset for each species. The number within each shape denotes the number of independent seasons of data was summarized for that habitat at that location

estuaries, and (3) the weighted mean density in the structured habitat minus the unstructured control density was positive (Figure 1). The weighted mean density was derived independently for each structured habitat and its paired unstructured control. The mean density for each species was estimated assuming a hierarchical Gaussian model, where mean densities from individual bays $(i)$ in the northern Gulf of Mexico contribute equally to a habitat-specific density $\left(d_{\mathrm{j}}\right)$. The average density in a given bay, $d_{\mathrm{ji}}$, was assumed to be a draw from an overall population distribution that was normal. Individual studies within a bay were assumed to be noisy measurements of that mean and are represented as draws from a normal distribution with mean $d_{\mathrm{ji}}$ and standard deviation $s_{\mathrm{ji}}$. We estimated the density of a species in each habitat in each bay $\left(d_{\mathrm{ji}}\right)$ by averaging overall studies for the given bay, inverse weighted by the uncertainty in each measurement. To estimate the Gulf of Mexico-wide habitat-specific mean $\left(D_{\mathrm{j}}\right)$, the mean density $\left(d_{\mathrm{ji}}\right)$ for each bay contributed equally. This protocol was used to determine whether criteria 3 was fulfilled. The uncertainty in $D_{\mathrm{j}}$ (i.e., $S$ ) was estimated from the sample standard deviation of the bay estimates. This measure of uncertainty was then used to estimate the uncertainty in the resulting approximations of production from enhancement by structured habitats.

\section{Estimating Productivity and Uncertainty}

Density enhancement equaled the number of YOY individuals per $\mathrm{m}^{2}$ of structured habitat in the system over and above that recorded in the unstructured control. The production model, which sums the survival and growth of the individuals attributed to the presence of the structured habitat, was seeded with density enhancement values drawn from a Gaussian distribution based on the field-derived data. Because only species identified as enhanced by structured habitat were modeled, the density was set to zero if a negative value was drawn from the distribution, and the distribution was corrected to account for this such that the overall mean and standard deviation reflected the field data on YOY individuals (sensu $\mathrm{zu}$ Ermgassen et al. 2016). In order to derive estimates of uncertainty in the production values, ten thousand independent density enhancements were randomly drawn from the distribution to seed the production model.

Production values were derived by applying the von Bertalanffy growth equation and size-dependent mortality as estimated by Lorenzen (2000) to the ten thousand independent density enhancements drawn randomly from the Gaussian distribution. The result was an estimate of the biomass per unit area per year that could be attributed to each recruitmentenhanced species. The size-dependent mortality (M) 
relationship outlined in Lorenzen (2000) applies higher mortality rates to smaller individuals of a given species. The model was informed by a single estimate of $M$ at the length of maturity $\left(L_{\mathrm{m}}\right.$; see Table S2).

Life history parameters were identified from FishBase (Froese and Pauly 2011) and through independent literature searches. Where multiple sources of life history parameters were available, preference was given to those most proximal to the northern Gulf of Mexico. If we were unable to identify species-specific parameters, we sought proxy parameters from the same genus and of roughly the same max length or we estimated $L_{\text {inf }}$ from $L_{\max }$ (Froese and Binohlan 2000) and calculated $K$ by substitution from the von Bertalanffy growth equation, assuming a $t_{0}$ of 0 . Where $L_{\mathrm{m}}$ was not reported, it was estimated from $L_{\text {inf }}$ (Froese and Binohlan 2000). Finally, where $K$ was known but $t_{0}$ unknown, $t_{0}$ was estimated from $L_{\text {inf }}$ and $K$ (Froese and Pauly 2011). The life history parameters that were used can be found in Table S2. It is widely accepted that life history parameters are estimates which have their own associated uncertainty and natural variability and that uncertainty increases in data poor species (Thorson et al. 2017). Estimates of uncertainty associated with life history parameters are, however, largely unknown and therefore were not able to be incorporated into this model and the resulting estimates of production enhancement.

The production enhancement estimate captures the full lifetime production of the individuals which were recruitment enhanced by the structured habitat or can also be considered to be an estimated annual enhancement value. Only natural mortality is accounted for in the resulting estimates. A summary overview of the steps taken as described above can be found in Figure S3.

\section{Applying Enhancement Estimates to Case Study Locations}

To illustrate the application of these habitat-specific species production enhancement estimates, we identified two locations within the northern Gulf of Mexico for which the current habitat extent of seagrass, oyster reef, and salt marsh edge habitats are known. We chose the entire estuaries of Galveston Bay, TX (including East Bay, West Bay, and Trinity Bay), and Pensacola Bay, FL (including Escambia Bay, East Bay, Blackwater Bay, and the entirety of Santa Rosa Sound) (Figure 2).

Seagrass habitat estimates were based on the most recent data from each state. In the case of Galveston, TX, data were collected by the Texas Parks and Wildlife Department Coastal Fisheries Division Habitat Assessment Team in 2015. We used 2010 habitat data compiled for Pensacola, FL, by the Fish and Wildlife Research Institute as part of their Seagrass Integrated Mapping and Monitoring Report (Yarbro and Carlson 2016). Oyster reef habitat estimates are also based on the most recent oyster habitat data from each state. In the case of Pensacola Bay, data collected in 2009-2010 originated from the Florida Department of Agriculture and Consumer Services. Oyster data for Galveston Bay were collected in 2008 by Texas A\&M as part of a survey funded by the Texas General Land Office.

Salt marsh edge represents a 3-m buffer along the coastline that represents the shoreward edge of known salt marsh habitat. Salt marsh habitat was extracted from NOAA's Coastal Change Analysis Program (CCAP) Regional Land Cover Data (NOAA 2019), which was derived in 2010 and provided as a raster with $30-\mathrm{m}$ resolution. The coastline was derived from the annually updated NOAA's Continuously Updated Shoreline dataset (CUSP; accessed January 2019). To combine both datasets, we first converted each salt marsh patch to a polygon and cleaned the areas $<2$ cells $\left(<1800 \mathrm{~m}^{2}\right)$ or over water. To fill the gaps between the higher-resolution coastline and the salt marsh polygon, we calculated a $30-\mathrm{m}$ buffer around each salt marsh polygon and considered as salt marsh the areas that fell between known salt marsh and the coastline, thus representing 1-cell gaps that were considered water in the CCAP data. Finally, we intersected the new salt marsh polygons with a $3-\mathrm{m}$ buffer around the coastline $(1.5 \mathrm{~m}$ on each side).

The list of species enhanced by each habitat in the northern Gulf of Mexico was reviewed by fisheries independent monitoring experts from both of the case study areas. Species that were identified as consistent recruits at the site were included in the site-specific estimates of fish and mobile crustacean productivity. Species identified as incidental or rarely present were discarded and not included in the site-specific estimates. This selection was undertaken to ensure that the site-based estimates of fish and mobile invertebrate production did not assign a Gulf of Mexico mean production estimate to species which are rare or incidental in the case study location, thus providing a conservative estimate of enhancement at these locations. The contribution of the current extent of each habitat to the number of young-of-year individuals entering the population annually and the production that can be attributed to this recruitment enhancement were then determined by multiplying the density enhancement and production enhancement values by the amount of each structured habitat in each bay.

\section{Results}

Of the 87 species represented in sampling from seagrass habitats, $25(29 \%)$ were enhanced relative to the unstructured control (Table 1). In oyster reef habitat, 20 of 61 (33\%) and, in salt marsh edge, 25 of 57 (44\%) species were enhanced relative to the unstructured control. In each habitat, many species were unable to be assessed because of insufficient data 


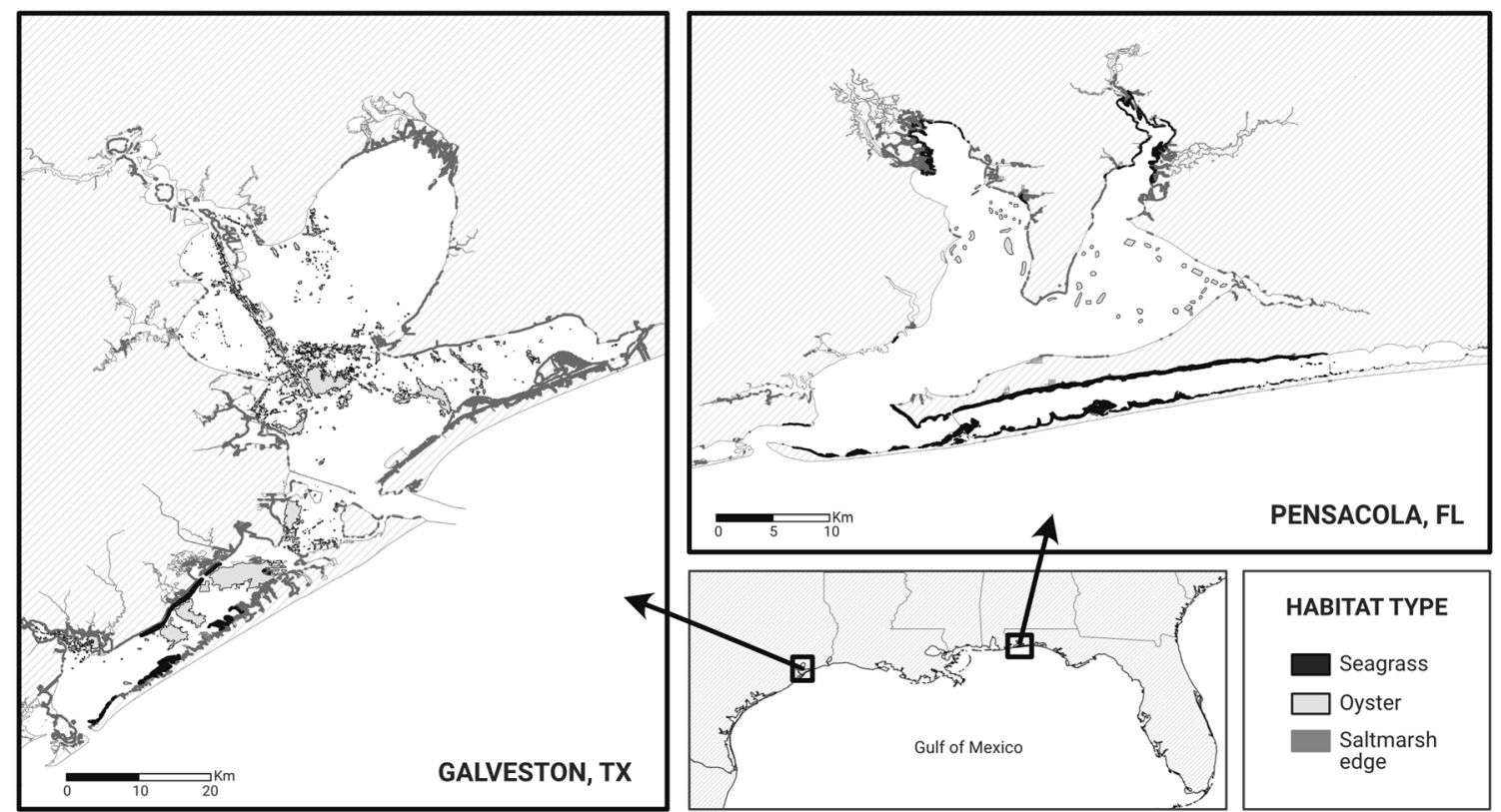

Fig. 2 Map showing the extent of seagrass, oyster reef, and salt marsh edge habitat in the case study estuaries: (a) Galveston Bay, Texas, and (b) Pensacola Bay, Florida

(Table 1); 47 species overall were data deficient or not recorded in the dataset from across all three habitats (Table S4). Considering only species represented by sufficient data, more species were found to be enhanced than not for each structured habitat (Table 1). A total of 40 species were enhanced by at least one of the structured habitats, while eight species were enhanced by all three habitats (Table 2). Twelve of the 40 enhanced species are commercially or recreationally important in the region, including blue crab (Callinectes sapidus), spotted seatrout (Cynoscion nebulosus), gray snapper (Lutjanus griseus), southern flounder (Paralichthys lethostigma), brown shrimp (Farfantepenaeus aztecus), pink shrimp ( $F$. duorarum), and white shrimp (Litopenaeus setiferus).

The total biomass production enhancement estimated to result from this nursery function of the habitats totaled 1370.3 [SD 317.1] $\mathrm{g} \mathrm{m}^{2} \mathrm{y}^{-1}$ for seagrasses, 650.6 [SD 114.0 ] $\mathrm{g} \mathrm{m}^{2} \mathrm{y}^{-1}$ for oyster reefs, and 1222.0 [SD 189.7] $\mathrm{g}$ $\mathrm{m}^{2} \mathrm{y}^{-1}$ for salt marsh edge (Table 2). Commercially or recreationally important species comprised the vast majority of productivity from all three habitats (Figure 3 ). Commercial species accounted for 1231.0 [SD 317.0] $\mathrm{g} \mathrm{m}^{2} \mathrm{y}^{-1}$ (90\%) for seagrasses, 470.0 [SD 110.2] $\mathrm{g} \mathrm{m}^{2} \mathrm{y}^{-1}(72 \%)$ for oyster reefs, and 1023.3 [SD 186.3] $\mathrm{g} \mathrm{m}^{2} \mathrm{y}^{-1}$ (84\%) for salt marsh edge (Figure 3).

\section{Case Study Results}

In Galveston Bay, the three structured coastal habitats examined are estimated to contribute 54,567 [SD 9756] tonnes $\mathrm{y}^{-1}$ of fish and crustaceans to the Gulf of Mexico, over and above what would be provided in their absence, of which $76 \%$ $\left(41,298\right.$ [SD 9541] tonnes $\left.\mathrm{y}^{-1}\right)$ represented commercially or recreationally important species (Figure 4). Oyster reefs had the greatest spatial extent of the three habitats in the bay (10,548 ha, Figure 4) and enhanced 10 fish and invertebrate species with a total biomass of 45,105 [SD 9584] tonnes $\mathrm{y}^{-1}$ within the estuary. Five of the ten species enhanced by oyster reefs had commercial or recreational value (32,641 [SD 9367] tonnes $\mathrm{y}^{-1}$; Figure 4 ; Table 3 ). The two largest contributors to enhanced production of fish and crustaceans from oyster reefs were sheepshead $\left(17,798\right.$ [SD 6684] tonnes $\left.^{-1}\right)$ and white shrimp (8191 [SD 4662] tonnes $\mathrm{y}^{-1}$ ) (Table 3). Seagrass and salt marsh edge habitats covered 799ha and 211 ha,
Table 1 Summary of the number of species represented in the dataset for each species and the number enhanced, data deficient, or not enhanced by each habitat

\begin{tabular}{lcccc}
\hline Habitat & $\begin{array}{l}\text { Number of } \\
\text { species }\end{array}$ & $\begin{array}{l}\text { Number of species } \\
\text { enhanced }\end{array}$ & $\begin{array}{l}\text { Number of species data } \\
\text { deficient }\end{array}$ & $\begin{array}{l}\text { Not } \\
\text { enhanced }\end{array}$ \\
\hline Seagrass & 87 & 25 & 46 & 16 \\
Oyster & 61 & 20 & 26 & 15 \\
Salt marsh & 57 & 25 & 15 & 17 \\
$\quad$ edge & & & & \\
\hline
\end{tabular}




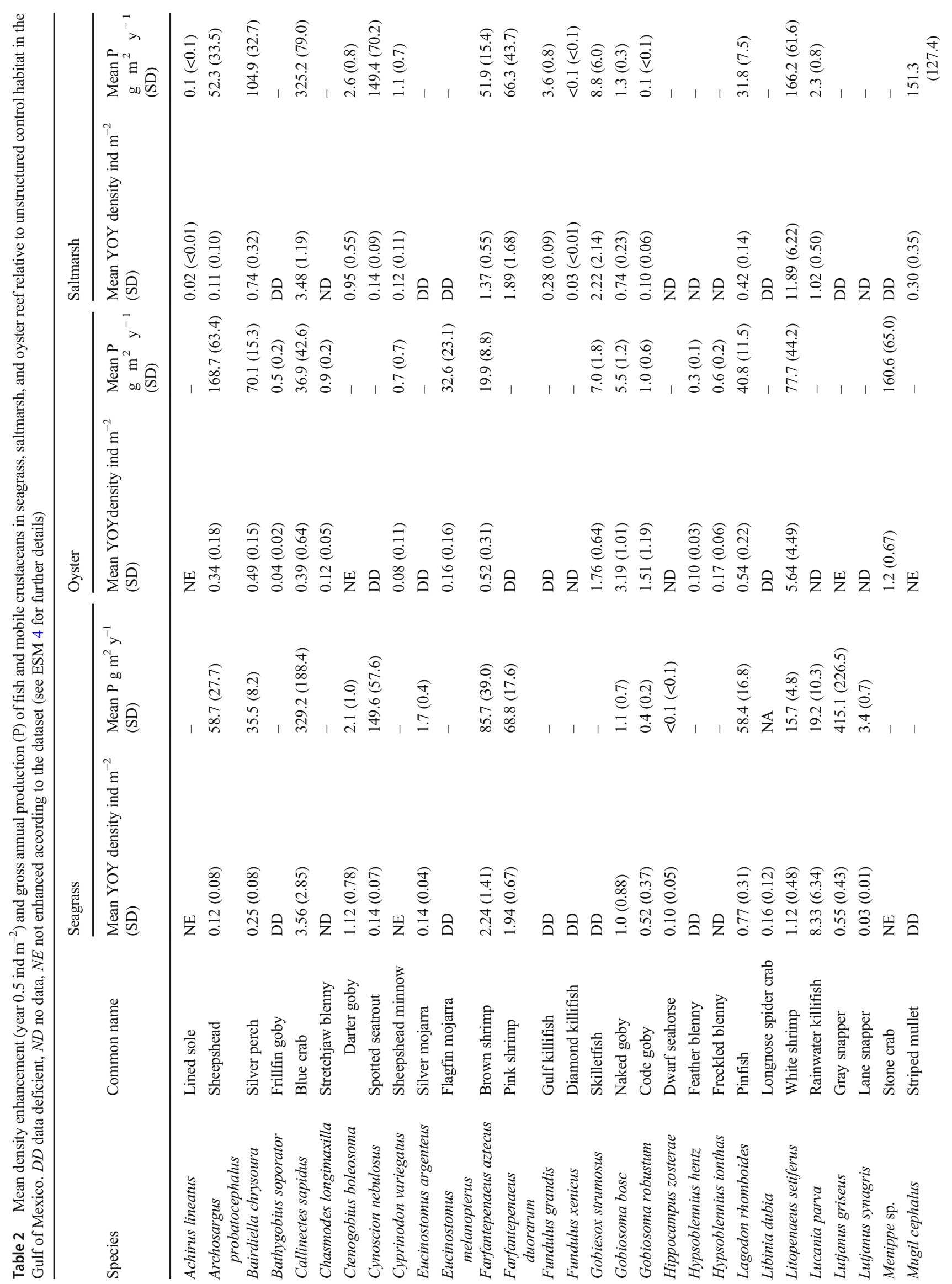




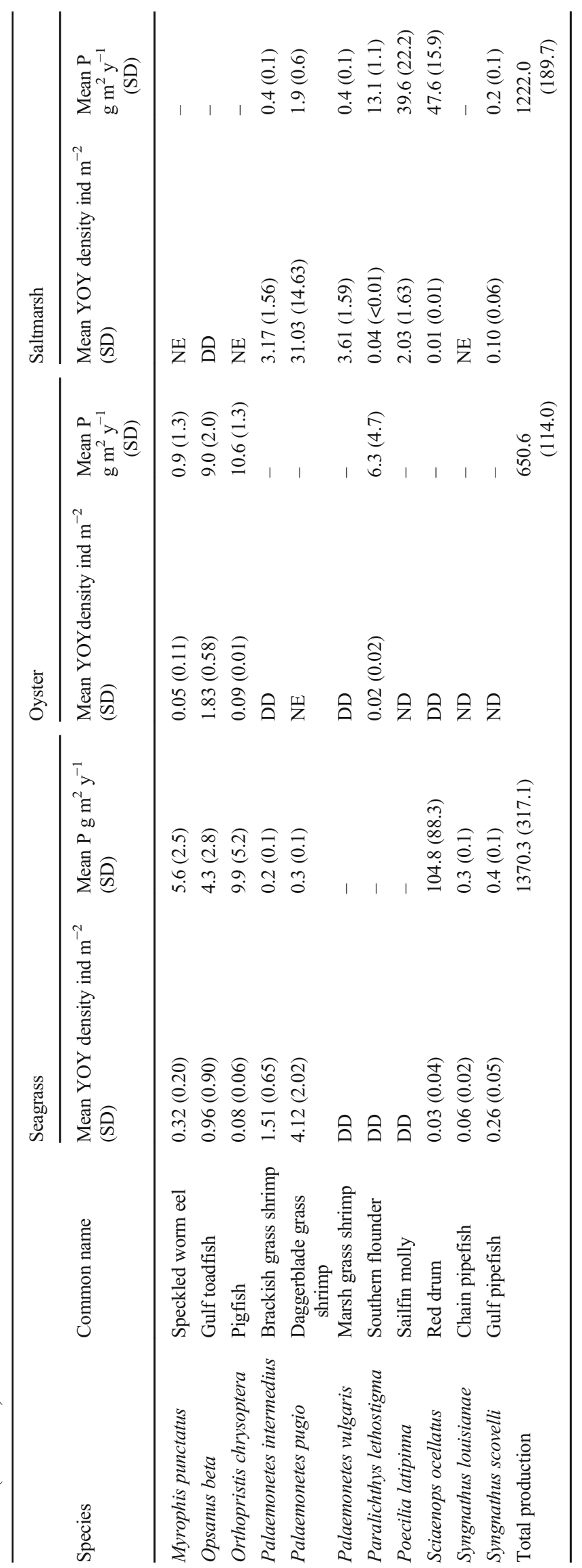


Fig. 3 Box-whisker plot showing the potential production enhancement per $\mathrm{m}^{2}$ of habitat from all species and from commercial and recreationally important species alone, for each habitat: seagrass, oyster reef, and salt marsh edge.

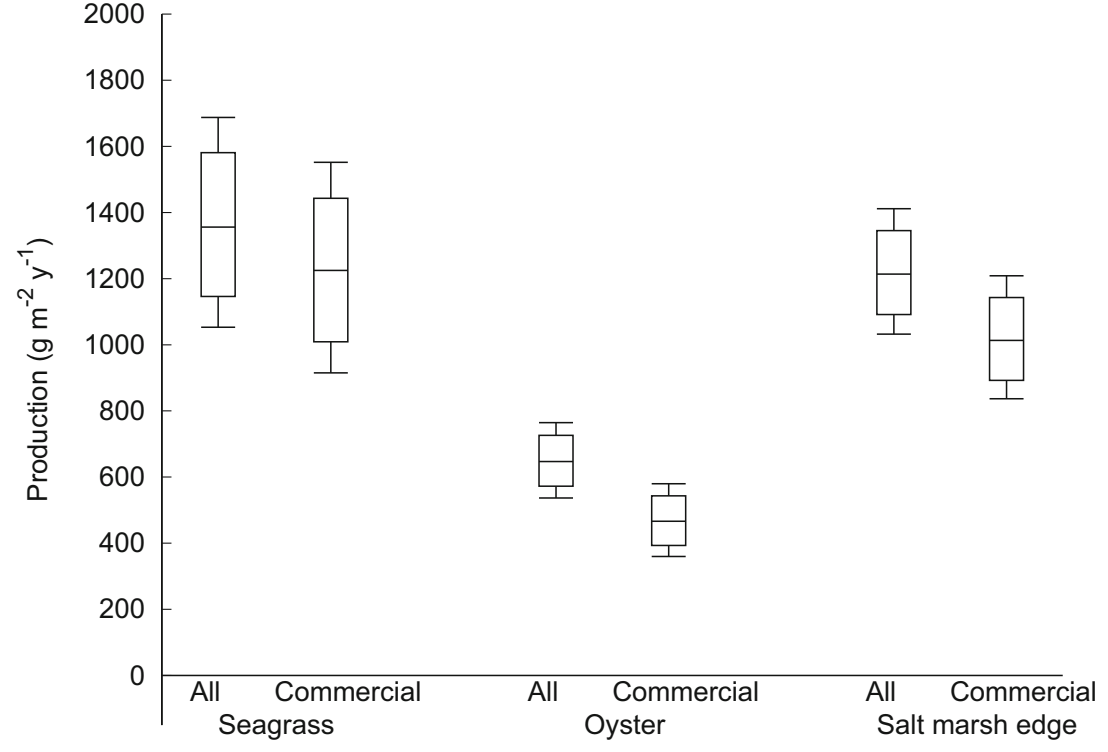

respectively, and enhanced production of fish and invertebrate species by 7273 [SD 1779] tonnes $\mathrm{y}^{-1}$ and 2558 [SD 403] tonnes $\mathrm{y}^{-1}$, respectively (Figure 4 ). It is worth noting that this estimate represents the productivity from the 3-m-wide defined salt marsh edge only and that any fish and invertebrate production derived from the $\sim 19,200$ ha of inner salt marsh in the bay is not included in this estimate. The two largest contributors to enhanced production of fish and crustaceans from the current seagrass extent of Galveston bay were blue crab (2631 [SD 1505] tonnes $\mathrm{y}^{-1}$ ) and spotted seatrout (1196 [SD 461] tonnes $\mathrm{y}^{-1}$ ), while 9 of the 20 species enhanced by salt marsh edge were commercially or recreationally important and contribute 2164 [SD 394] tonnes $\mathrm{y}^{-1}$. This included blue crab (688 [SD 167] tonnes $\mathrm{y}^{-1}$ ), all three commercial shrimp species (totaling 601 [SD 163] tonnes $\mathrm{y}^{-1}$ ), and striped mullet (320 [SD 270] tonnes $\mathrm{y}^{-1}$ ) (Table 3; Figure 4).

On a per unit area basis, salt marsh edge habitat contributed the greatest amount of production enhancement in Galveston Bay (1210 [SD 190] $\mathrm{g} \mathrm{m}^{-2} \mathrm{y}^{-1}$ ) from 18 consistently present species. Seagrass habitats contributed the second greatest production enhancement per unit area (910 [SD 223] $\mathrm{g} \mathrm{m}^{-2} \mathrm{y}^{-1}$ ) from 13 species, while oyster reefs provide an estimated production enhancement of 428 [SD 91] $\mathrm{g} \mathrm{m}^{-2} \mathrm{y}^{-1}$ from nine species (Figure 5; Table S5).

In Pensacola Bay, the three structured coastal habitats contributed 19,859 [SD 4141] tonnes $\mathrm{y}^{-1}$ of fish and invertebrates to the Gulf of Mexico (Figure 4) over and above what would be provided were they replaced by unstructured habitat. The spatial extent of seagrass habitat was greater than the other two habitats in the bay (1296 ha, Figure 2). Seagrasses contributed 16,753 [SD 4103] tonnes $\mathrm{y}^{-1}$ from 16 enhanced species consistently recruiting within the bay. Seagrass habitat produced 15,194 [SD 4093] tonnes $\mathrm{y}^{-1}(91 \%)$ that can be attributed to eight commercially or recreationally important species. The three recreationally or commercially important species contributing the greatest production enhancement were gray snapper (5380 [SD 2935] tonnes $\mathrm{y}^{-1}$ ), blue crab (4267 [SD 2441] tonnes $\mathrm{y}^{-1}$ ), and spotted seatrout (1939 [SD 747] tonnes $\mathrm{y}^{-1}$ ). Oyster reef extent in Pensacola Bay was approximately half that of seagrasses (599 ha) and contributed 2486 [SD 551] tonnes $\mathrm{y}^{-1}$ enhancement in production of seven species (Table 3 ). Salt marsh edge extent in Pensacola Bay was limited to 54 ha, and yet, it contributed a total of 620 [SD 102] tonnes $y^{-1}$, of which 520 [SD 99] tonnes $\mathrm{y}^{-1}(84 \%)$ can be attributed to seven commercially or recreationally important species including blue crab (176 [SD 43] tonnes $\mathrm{y}^{-1}$ ), spotted seatrout (81 [SD 38] tonnes $\mathrm{y}^{-}$ ${ }^{1}$ ), all three commercial shrimp species (totaling 154 [SD 42] tonnes $\left.\mathrm{y}^{-1}\right)$, and striped mullet (82 [SD 69] tonnes $\mathrm{y}^{-1}$ ) (Table 3).

On a per unit area basis, seagrass and salt marsh edge habitats in Pensacola Bay contributed similar amounts of production enhancement (1292 [SD 317] and 1142 [SD 188] g $\mathrm{m}^{-2} \mathrm{y}^{-1}$, respectively) from 16 species in each case. Oyster reefs in contrast enhanced eight species within the bay, resulting in a production enhancement of 415 [SD 92] $\mathrm{g} \mathrm{m}^{-2}$ $\mathrm{y}^{-1}$ (Figure 5; Table S5).

\section{Discussion}

Enhanced fish production, the additional biomass that is produced per year as a result of the presence of each structured habitat, represents an important ecosystem function that supports valuable recreational and commercial fisheries, both directly and through the provision of forage species. Our quantitative approach revealed that seagrass, salt marsh edge, and oyster reef habitats all enhance fish and invertebrate 
Table 3 Production enhancement by species (tonnes year ${ }^{-1}$ ) from existing extents of structured coastal habitats for each of the case study locations: Galveston Bay, Texas, and Pensacola Bay, Florida. Standard deviation given in brackets. *indicates species which are commercially or recreationally important

\begin{tabular}{|c|c|c|c|c|c|c|c|}
\hline \multirow[t]{3}{*}{ Species } & \multirow[t]{3}{*}{ Common name } & \multicolumn{6}{|c|}{ Production enhancement arising from existing habitat (tonnes year ${ }^{-1}$ ) } \\
\hline & & \multicolumn{3}{|c|}{ Galveston Bay } & \multicolumn{3}{|c|}{ Pensacola Bay } \\
\hline & & Seagrass & Oyster & Salt marsh edge & Seagrass & Oyster & Salt marsh edge \\
\hline $\begin{array}{l}\text { Archosargus } \\
\quad \text { probatocephalus }\end{array}$ & Sheepshead* & $\begin{array}{l}469 \\
(222)\end{array}$ & $\begin{array}{l}17,798 \\
(6684)\end{array}$ & $\begin{array}{l}111 \\
(71)\end{array}$ & 0 & 0 & 0 \\
\hline Bairdiella chrysoura & Silver perch & $\begin{array}{l}284 \\
(65)\end{array}$ & $\begin{array}{l}7397 \\
(1614)\end{array}$ & $\begin{array}{l}222 \\
(69)\end{array}$ & $\begin{array}{l}460 \\
(106)\end{array}$ & $\begin{array}{l}420 \\
(92)\end{array}$ & $\begin{array}{l}57 \\
(18)\end{array}$ \\
\hline Callinectes sapidus & Blue crab* & $\begin{array}{l}2631 \\
\quad(1505)\end{array}$ & $\begin{array}{l}3896 \\
(4498)\end{array}$ & $\begin{array}{l}688 \\
(167)\end{array}$ & $\begin{array}{l}4267 \\
(2441)\end{array}$ & $\begin{array}{l}221 \\
(256)\end{array}$ & $\begin{array}{l}176 \\
(43)\end{array}$ \\
\hline Ctenogobius boleosoma & Darter goby & $\begin{array}{l}16 \\
(8)\end{array}$ & 0 & $\begin{array}{l}4 \\
(2)\end{array}$ & $\begin{array}{l}27 \\
(13)\end{array}$ & 0 & $\begin{array}{l}1 \\
(<1)\end{array}$ \\
\hline Cynoscion nebulosus & Spotted seatrout* & $1196(461)$ & 0 & $\begin{array}{l}316 \\
(148)\end{array}$ & $\begin{array}{l}1939 \\
(747)\end{array}$ & 0 & $\begin{array}{l}81 \\
(38)\end{array}$ \\
\hline Cyprinodon variegatus & Sheepshead minnow & 0 & $\begin{array}{l}77 \\
(77)\end{array}$ & $\begin{array}{l}2 \\
(2)\end{array}$ & 0 & 0 & 0 \\
\hline Farfantepenaeus aztecus & Brown shrimp* & $\begin{array}{l}685 \\
(311)\end{array}$ & $\begin{array}{l}2097 \\
(926)\end{array}$ & $\begin{array}{l}110 \\
(33)\end{array}$ & $\begin{array}{l}1111 \\
(505)\end{array}$ & $\begin{array}{l}119 \\
(53)\end{array}$ & $\begin{array}{l}28 \\
(8)\end{array}$ \\
\hline Farfantepenaeus duorarum & Pink shrimp* & $\begin{array}{l}550 \\
(141)\end{array}$ & 0 & $\begin{array}{l}140 \\
(93)\end{array}$ & $\begin{array}{l}892 \\
(228)\end{array}$ & 0 & $\begin{array}{l}36 \\
(24)\end{array}$ \\
\hline Fundulus grandis & Gulf killifish & 0 & 0 & $\begin{array}{l}8 \\
(2)\end{array}$ & 0 & 0 & 0 \\
\hline Gobiosoma bosc & Naked goby & $\begin{array}{l}8 \\
(5)\end{array}$ & $\begin{array}{l}580 \\
(129)\end{array}$ & $\begin{array}{l}3 \\
(1)\end{array}$ & 0 & 0 & 0 \\
\hline Gobiosoma robustum & Code goby & $\begin{array}{l}3 \\
(1)\end{array}$ & $\begin{array}{l}109 \\
(62)\end{array}$ & $\begin{array}{l}<1 \\
(<1)\end{array}$ & 0 & 0 & 0 \\
\hline Lagodon rhomboides & Pinfish & $\begin{array}{l}467 \\
(134)\end{array}$ & $\begin{array}{l}4301 \\
(1215)\end{array}$ & $\begin{array}{l}67 \\
(16)\end{array}$ & $\begin{array}{l}757 \\
(218)\end{array}$ & $\begin{array}{l}244 \\
(69)\end{array}$ & $\begin{array}{l}17 \\
(4)\end{array}$ \\
\hline Litopenaeus setiferus & White shrimp* & $\begin{array}{l}125 \\
(38)\end{array}$ & $\begin{array}{l}8191 \\
(4662)\end{array}$ & $\begin{array}{l}351 \\
(130)\end{array}$ & $\begin{array}{l}203 \\
(62)\end{array}$ & $\begin{array}{l}465 \\
(265)\end{array}$ & $\begin{array}{l}90 \\
(33)\end{array}$ \\
\hline Lucania parva & Rainwater killifish & 0 & 0 & 0 & $\begin{array}{l}248 \\
(113)\end{array}$ & 0 & $\begin{array}{l}1 \\
(<1)\end{array}$ \\
\hline Lutjanus griseus & Gray snapper* & 0 & 0 & 0 & $\begin{array}{l}5380 \\
(2935)\end{array}$ & 0 & 0 \\
\hline Lutjanus synagris & Lane snapper* & 0 & 0 & 0 & $\begin{array}{l}44 \\
(10)\end{array}$ & 0 & 0 \\
\hline Menippe sp. & Stone crab* & 0 & 0 & 0 & 0 & $\begin{array}{l}962 \\
(390)\end{array}$ & 0 \\
\hline Mugil cephalus & Striped mullet* & 0 & 0 & $\begin{array}{l}320 \\
(270)\end{array}$ & 0 & 0 & $\begin{array}{l}82 \\
(69)\end{array}$ \\
\hline Opsanus beta & Gulf toadfish & 0 & 0 & 0 & $\begin{array}{l}56 \\
(37)\end{array}$ & $\begin{array}{l}54 \\
(12)\end{array}$ & 0 \\
\hline Palaemonetes intermedius & Brackish grass shrimp & 0 & 0 & 0 & $\begin{array}{l}2 \\
(1)\end{array}$ & 0 & $\begin{array}{l}<1 \\
(<1)\end{array}$ \\
\hline Palaemonetes pugio & $\begin{array}{l}\text { Daggerblade grass } \\
\text { shrimp }\end{array}$ & $\begin{array}{l}2 \\
(1)\end{array}$ & 0 & $\begin{array}{l}4 \\
(1)\end{array}$ & $\begin{array}{l}3 \\
(1)\end{array}$ & 0 & $\begin{array}{l}1 \\
(<1)\end{array}$ \\
\hline Palaemonetes vulgaris & Marsh grass shrimp & 0 & 0 & 0 & 0 & 0 & $\begin{array}{l}<1 \\
(<1)\end{array}$ \\
\hline Paralichthys lethostigma & Southern flounder* & 0 & $\begin{array}{l}659 \\
(494)\end{array}$ & $\begin{array}{l}28 \\
(2)\end{array}$ & 0 & 0 & 0 \\
\hline Poecilia latipinna & Sailfin molly & 0 & 0 & $\begin{array}{l}84 \\
(47)\end{array}$ & 0 & 0 & $\begin{array}{l}21 \\
(12)\end{array}$ \\
\hline Sciaenops ocellatus & Red drum* & $\begin{array}{l}837 \\
(705)\end{array}$ & 0 & $\begin{array}{l}101 \\
(34)\end{array}$ & $\begin{array}{l}1358 \\
(1144)\end{array}$ & 0 & $\begin{array}{l}26 \\
(9)\end{array}$ \\
\hline Syngnathus scovelli & Gulf pipefish & 0 & 0 & 0 & $\begin{array}{l}5 \\
(1)\end{array}$ & 0 & $\begin{array}{l}<1 \\
(<1)\end{array}$ \\
\hline
\end{tabular}


Table 3 (continued)

\begin{tabular}{|c|c|c|c|c|c|c|}
\hline \multirow[t]{3}{*}{ Common name } & \multicolumn{6}{|c|}{ Production enhancement arising from existing habitat (tonnes year ${ }^{-1}$ ) } \\
\hline & \multicolumn{3}{|c|}{ Galveston Bay } & \multicolumn{3}{|c|}{ Pensacola Bay } \\
\hline & Seagrass & Oyster & Salt marsh edge & Seagrass & Oyster & Salt marsh edge \\
\hline Total production enhancement (tonnes/year) & $\begin{array}{l}7273 \\
(1779)\end{array}$ & $\begin{array}{l}45,105 \\
\quad(9584)\end{array}$ & $2558(403)$ & $\begin{array}{l}16,753 \\
\quad(4102)\end{array}$ & $\begin{array}{l}2486 \\
(551)\end{array}$ & $\begin{array}{l}620 \\
(102)\end{array}$ \\
\hline $\begin{array}{l}\text { Total production enhancement comm./rec. important } \\
\text { species (tonnes/year) }\end{array}$ & $\begin{array}{l}6493 \\
(1773)\end{array}$ & $\begin{array}{l}32,641 \\
\quad(9367)\end{array}$ & $2164(394)$ & $\begin{array}{l}15,194 \\
(4093)\end{array}$ & $\begin{array}{l}1768 \\
(539)\end{array}$ & $\begin{array}{l}520 \\
(99)\end{array}$ \\
\hline
\end{tabular}

production well beyond unstructured bottom (Table 2, Figure 3). We demonstrated how to apply this method to specific embayments where the spatial extent of each habitat is known, thereby quantifying the individual and collective contributions of each habitat, as well as the potential additional production per unit area of habitat added. Both the Gulf of Mexico-wide habitat-specific enhancement estimates and the illustrated application of them to specific embayments have the potential to inform marine fishery habitat conservation and restoration actions. Such a tool for evaluating conservation actions has been identified as a management need (Lederhouse and Link 2016).

While all three habitats enhance fish production in the coastal estuaries of the Gulf of Mexico, we found that the composition of enhanced species differed substantially among habitats (Table 2). Each habitat enhanced 20-25 fish and invertebrate species of a total of 40 unique species. Of those 40 , only eight species were enhanced across all three habitats, although 21 species were enhanced in all habitats for which they were not data deficient (Table 2). The 8 species enhanced across all habitats were dominated, as would be expected, by species well known to associate with structured habitats, such as sheepshead, blennies, shrimps, and blue crab. Not all structure-affiliated species were, however, universally enhanced. For example, we found that pigfish (Orthopristis chrysoptera) was not enhanced by salt marsh edge habitat (Table 2). Also of note, spot (Leiostomus xanthurus) was not enhanced by any of the three structured habitats (Table S5). This species had been identified as enhanced in earlier efforts to quantify enhancement by oyster reef habitats (Peterson et al. 2003; zu Ermgassen et al. 2016), yet species-specific studies have illustrated that juvenile spot do not associate closely with structured habitats, but rather prefer areas rich in their preferred prey of copepods and nematodes (Miltner et al. 1995; Winemiller 2015).

Previous studies have reported that oyster reefs located next to fringing habitats do not necessarily enhance juvenile fish abundances and that this lack of enhancement may be due to oyster reefs being functionally redundant to adjacent seagrass and salt marsh areas (Grabowski et al. 2005; Geraldi et al.
2009). The method presented here does not account for habitat quality or landscape setting, which will also influence the degree to which habitats enhance fish and invertebrate productivity (Grabowski et al. 2005; Schloesser and Fabrizio 2019). Rather, our method produces mean estimates of enhancement that incorporate the range of habitat variability (both biotic and abiotic) that existed across the hundreds of field samples that inform the estimates for each habitat (Table S1). Although we did not examine whether landscape setting affects the degree to which these habitats augment fish production, our findings suggest that the communities augmented by each habitat type differ at local and regional scales, which has also been identified in another recent meta-analysis (Hollweg et al. 2020a). Efforts to enhance the functioning of coastal and estuarine ecosystems through habitat protection and restoration will benefit from managing these habitats collectively and in consideration with other habitats recognized as EFH such as coral reefs, kelp beds, and mangroves.

Overall enhancement also varied greatly by habitat: enhanced production by seagrass and salt marsh edge habitats was twice that of oyster reef habitat. Hollweg et al. (2020a) also found that communities associated with salt marsh and seagrass habitats were more similar to each other than to those in oyster reefs, a finding that is supported by this study. This difference could reflect the greater degree of structural complexity provided by these vegetated habitats relative to oyster reefs, as juvenile fish and invertebrate survival likely scales positively with habitat complexity (Crowder and Cooper 1982), as well as the greater contribution of seagrasses and salt marsh edge to primary production. Differences in sampling efficiency among habitats may also have contributed to this finding. While only sampling methods designed to target YOY or resident species were included in the dataset (Table S1) and the dataset is dominated by enclosure traps, which are known to be highly efficient (Rozas and Minello 1997), it is nevertheless likely that differences in sampling efficiency exist among habitat types. Not all species that utilize the habitats are well sampled by the gears represented. While structured habitats often result in lower sampling efficiencies than unstructured habitats (Rozas and Minello 1997), the relative efficiency on different structured habitats is largely 


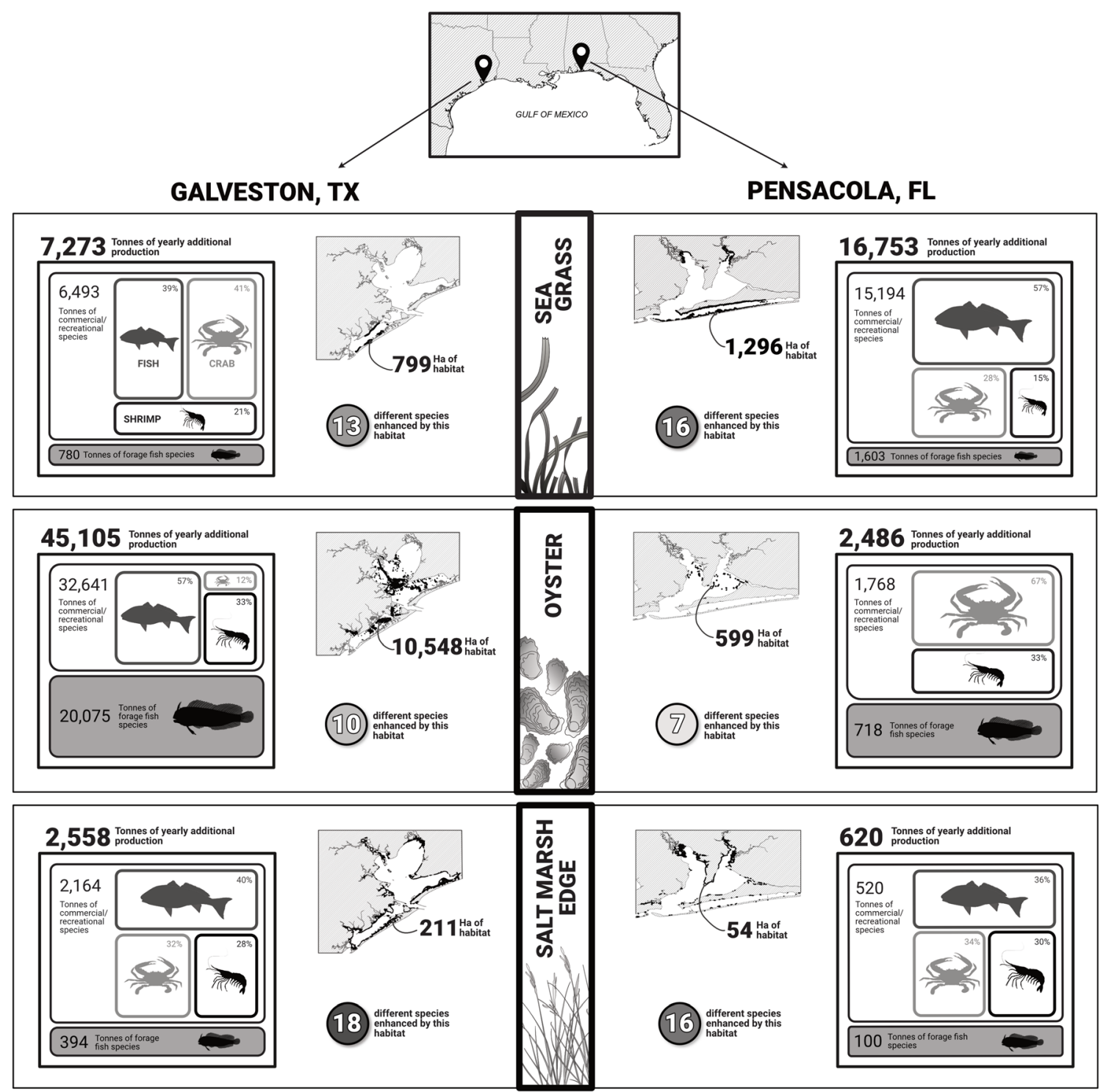

Fig. 4 The total production enhancement currently yielded on average per year from each of the three habitats at the case study sites Galveston Bay, Texas, and Pensacola Bay, Florida. The proportion (\%) of commercially or recreationally important species within each habitat

unknown. Higher sampling efficiency on unstructured habitats may result in our estimates of enhancement being overly conservative, whereas it is not possible to comment on the potential effect of differences in sampling efficiency among the structured habitats. Studies that advance our understanding of how gear efficiency and other sampling artifacts vary by habitat will enhance our ability to quantify and compare the amount of fish production derived from coastal habitats. One other factor that limits the ability to state conclusively the value of one habitat relative to another is the difference in sample size represented by each habitat in the dataset. While seagrass habitats are represented by 66 independent sampling units and salt marsh edge habitats are represented by 55 , oyster reefs are represented by just 28 independent sampling units which can be attributed to fish, crab, or shrimp species is depicted, as well as the case study-wide enhancement of forage species. Totals may differ from 100 due to rounding

(Figure 1). This difference in sampling effort represented in the habitats may also contribute to the lower number of species found to be enhanced by oyster reefs and the resulting lower production values relative to the other structured habitats.

lthough it is lower than the estimates for seagrass and salt marsh edge habitats, the updated estimate of fish and invertebrate production from Gulf of Mexico oyster reef habitats is higher than previously estimated by zu Ermgassen et al. (2016). In the earlier study, 19 species were enhanced by oyster reef habitat in the Gulf of Mexico, resulting in $528 \mathrm{~g}$ $\mathrm{m}^{-2} \mathrm{y}^{-1}$ of enhanced fish production, as compared to our current estimate of $650 \mathrm{~g} \mathrm{~m}^{-2} \mathrm{y}^{-1}$ from 20 species (zu Ermgassen et al. 2016, 2018). This modest increase in production is partly 
Fig. 5 Box-whisker plot showing the total production enhancement per $\mathrm{m}^{2}$ for estimates based on all species identified as enhanced within the Gulf of Mexico-wide and for the two case study sites, Galveston Bay, Texas, and Pensacola Bay, Florida

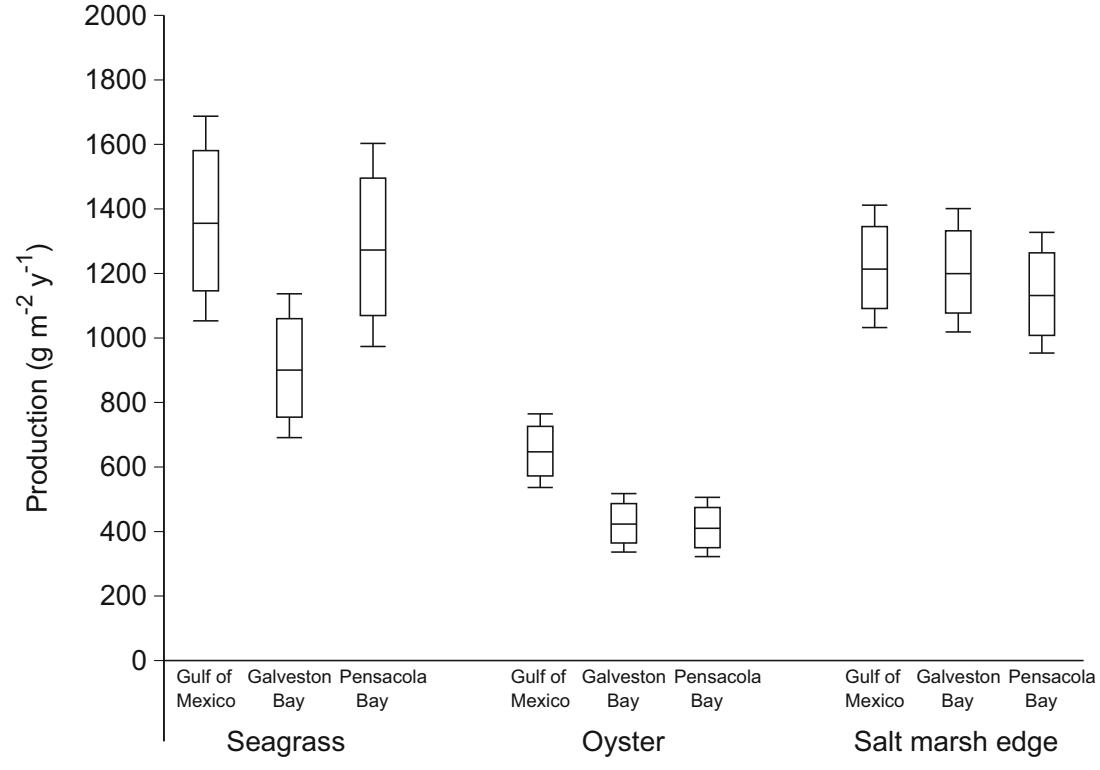

the result of including new datasets but likely also reflects changes in the method of estimating the mean density enhancement. In the zu Ermgassen et al. (2016) study, the mean was weighted by the number of independent samples represented in each data entry, but did not account for the confidence in any individual entry. The current methodology, on the other hand, weights each sample's contribution to the bayspecific mean by its standard error, and each location (e.g., bay or estuary) is equally weighted in determining the Gulfwide mean. This approach reduces bias from single measures with high densities resulting in overestimated augmentation values and likely provides a more robust measure of the Gulf-wide mean.

Although the identified enhanced species are dominated by forage species such as blennies, grass shrimp, and killifish (Table 2), the annual production resulting from the nursery function of these structured coastal habitats is dominated by recreationally and commercially important species (Figure 3). For example, red drum are enhanced by 0.03 ind $\mathrm{m}^{-2} \mathrm{y}^{-1}$ on seagrasses yet contribute $104.8 \mathrm{~g} \mathrm{~m}^{-2} \mathrm{y}^{-1}$, as compared to darter gobies which are enhanced by 1.12 ind $\mathrm{m}^{-2} \mathrm{y}^{-1}$ but contribute on average $2.1 \mathrm{~g} \mathrm{~m}^{-2} \mathrm{y}^{-1}$ (Table 2). This finding results from these important species having longer life spans and reaching much larger maximum sizes.

The two contrasting case studies illustrate the important role that habitat extent and the local suite of species have in determining the degree of production enhancement. While the total production enhancement within a bay is largely dictated by the extent of each of the structured habitats (Figure 4), the average production enhancement per unit area from any given habitat also varies between locations depending on which species are present. Furthermore, individual bay estimates for each habitat can vary substantially from those based on all species known to be enhanced in the Gulf of Mexico
(Figure 5; Table S5). It is striking, for example, that although oyster reefs in Pensacola Bay and Galveston Bay contribute approximately similar amounts of production enhancement per unit area (Figure 5), the proportion of that production from commercial crab species (stone crab and blue crab) in Pensacola Bay is $67 \%$, compared to just $12 \%$ in Galveston Bay, where stone crab are rare (Figure 4).

Structured coastal habitats benefit fish and invertebrates in numerous ways. In addition to providing nursery habitat, structured habitats often support later life history stages for many species (Coen et al. 1999; Peterson et al. 2003). For example, oysters comprise a substantial portion of the diet of large black drum, at least at certain times of the year (Brown et al. 2008). Black drum was not identified as enhanced in our study, because as young-of-year, black drum primarily feed on copepods and live over low salinity, unvegetated mud bottoms (Peters and McMichael 1990). Therefore, the value of oyster reefs in supporting black drum populations is not included in our estimates of productivity enhancement. Structured coastal habitats can also enhance fish production through exported carbon, which in turn supports productivity in offshore and estuarine systems not directly associated with the habitats in question (Deegan et al. 2000). The approach presented here results in the quantification of the nursery function of structured habitats derived from the enhancement (i.e., that which exceeds adjacent unstructured bottom) of the survival of juveniles directly occupying the habitat for those species for which there were sufficient data to assess. The approach does not account for the other ways in which structured coastal habitats support fish production such as habitat connectivity and ontogenetic diet shifts (Peterson et al. 2003; Sheaves et al. 2015). Our production estimates, therefore, represent just a portion of the total value to fish production that these habitats provide. 
Our production enhancement results are likely conservative yet robust given available data. While the well-identified problem of data deficiency and uncertainty in life history parameters may result in an underestimate of the uncertainty in production enhancement, the density enhancement with which the growth and mortality are estimated represent a greatly increased sample size since early efforts to quantify augmented fish production associated with oyster reefs (e.g., Peterson et al. 2003). Nevertheless, while our study is informed by multiple rigorous field studies investigating fish use of coastal habitats (Figure 1), the large number of species identified as data deficient are evidence that more field studies are needed to expand our ability to estimate the degree to which these habitats enhance fish production. Thus, our approach almost certainly underestimated enhanced fish production associated with seagrass, salt marsh edge, and oyster reefs in the Gulf of Mexico.

Ecosystem function quantifications that integrate spatial variability allow us to make smarter investments and better habitat protection and restoration decisions (Bradley et al. 2020). Central to this approach is locally accurate, spatially explicit quantification using metrics that can be applied by decision-makers at different scales (Spalding 2014; Cebrian et al. 2020). Our study aims to support the integration of coastal habitat conservation actions with the management of fisheries by providing the analytical tools necessary to make informed habitat protection and restoration decisions. Future work focusing on understanding how biotic and abiotic habitat variables impact these estimates at a more spatially explicit level would potentially help increase the predictive capacity of similar models. Our estimates, however, do represent an important first step to quantifying and communicating the importance of structured coastal habitats in supporting fish production, both through the provision of forage fish and through enhancing recruitment of recreationally and commercially important species (Figure 4).

Coastal habitats like seagrass beds, oyster reefs, and salt marshes serve as critical nurseries for economically and ecologically valuable fish and invertebrate species, providing access to food and shelter from predators (Thayer et al. 1978; Rozas and Minello 1998; Coen et al. 1999). Scientists and managers have generally assumed that when these habitats are degraded, the services they provide such as nursery habitat for valuable marine species are lost (Peterson and Lipcius 2003; Halpern et al. 2008). Therefore, state and federal agencies have long invested in coastal habitat conservation and restoration to recover lost fish production and other ecosystem services. However, these investments have often preceded the availability of, and thus would be enhanced by the development of, analytical tools capable of quantifying the ecosystem services expected from conservation actions and habitat restoration efforts. Approaches that integrate quantitative data representing spatial variability promote smarter investments in conservation and restoration decisions by allowing the value to be accounted for and the return on investment to be assessed. Central to this approach is locally accurate, spatially explicit quantification of ecosystem services using metrics that can be used at different scales as needed for coastal management decision-making (Spalding 2014). Our approach helps quantify the benefits of more species and a wider range of structured habitats than included in previous research (e.g., zu Ermgassen et al. 2016; Cebrian et al. 2020). Therefore, the results of our approach can be used across a broader range of real-world applications, including those related to fisheries management and allocation of limited conservation resources.

Supplementary Information The online version contains supplementary material available at https://doi.org/10.1007/s12237-021-00935-0.

Acknowledgements This research was supported via federal funds under award NA15NMF4690242 from the National Oceanic and Atmospheric Administration, US Department of Commerce. The authors would like to thank Dr. Megan La Peyre for offering her data and expertise.

\section{Declarations}

Disclaimer The scientific results and conclusions, as well as any views or opinions expressed herein, are those of the authors and do not necessarily reflect the views of NOAA or the Department of Commerce.

Open Access This article is licensed under a Creative Commons Attribution 4.0 International License, which permits use, sharing, adaptation, distribution and reproduction in any medium or format, as long as you give appropriate credit to the original author(s) and the source, provide a link to the Creative Commons licence, and indicate if changes were made. The images or other third party material in this article are included in the article's Creative Commons licence, unless indicated otherwise in a credit line to the material. If material is not included in the article's Creative Commons licence and your intended use is not permitted by statutory regulation or exceeds the permitted use, you will need to obtain permission directly from the copyright holder. To view a copy of this licence, visit http://creativecommons.org/licenses/by/4.0/.

\section{References}

Barbier, E.B., S.D. Hacker, C. Kennedy, E.W. Koch, A.C. Stier, and B.R. Silliman. 2011. The value of estuarine and coastal ecosystem services. Ecological Monographs 81 (2): 169-193.

Baumann, M.S., G.F. Fricano, K. Fedeli, C.E. Schlemme, M.C. Christman, and M.V. Carle. 2018. Recovery of salt marsh invertebrates following habitat restoration: Implications for marsh restoration in the northern Gulf of Mexico. Estuaries and Coasts. 43 (7): 1711-1721. https://doi.org/10.1007/s12237-018-0469-5.

Bradley, M., I. Nagelkerken, R. Baker, and M. Sheaves. 2020. Contextdependence: A conceptual approach for understanding the habitat relationships of coastal marine fauna. BioScience 70: 986-1004.

Brown, K.M., G.J. George, G.W. Peterson, B.A. Thompson, and J.H. Cowan Jr. 2008. Oyster predation by black drum varies spatially and seasonally. Estuaries and Coasts 31 (3): 597-604.

Cebrian, J., H. Liu, M. Christman, T. Hollweg, D.F. McCay, R. Balouskus, C. McManus, H. Ballestero, J. White, S. Friedman, and K. Benson. 2020. Standardizing estimates of biomass at recruitment and productivity for fin- and shellfish in coastal habitats. 
Estuaries and Coasts. 43 (7): 1764-1802. https://doi.org/10.1007/ s12237-019-00691-2.

Coen, L.D., M. Luckenbach, and D.L. Breitburg. 1999. The role of oyster reefs as essential fish habitat: A review of current knowledge and some new perspectives. Fish habitat: Essential fish habitat and rehabilitation. American Fisheries Society Symposium 22: 438-454.

Crowder, L.B., and W.E. Cooper. 1982. Habitat structural complexity and the interaction between bluegills and their prey. Ecology 63 (6): 1802-1813.

Deegan, L.A., J.E. Hughes, and R.A. Rountree. 2000. Salt marsh ecosystem support of marine transient species. In Concepts and Controversies in Tidal Marsh Ecology, ed. M.P. Weinstein and D.A. Kreeger, 333-365. Dordrecht: Springer.

Failler, P., É. Pètre, T. Binet, and J.-P. Maréchal. 2015. Valuation of marine and coastal ecosystem services as a tool for conservation: The case of Martinique in the Caribbean. Ecosystem Services 11: 67-75.

Folpp, H.R., H.T. Schilling, G.F. Clark, M.B. Lowry, B. Maslen, M. Gregson, and I.M. Suthers. 2020. Artificial reefs increase fish abundance in habitat-limited estuaries. Journal of Applied Ecology 57 (9): 1752-1761. https://doi.org/10.1111/1365-2664.13666.

Froese, R., and C. Binohlan. 2000. Empirical relationships to estimate asymptotic length, length at first maturity and length at maximum yield per recruit in fishes, with a simple method to evaluate length frequency data. Journal of Fish Biology 56 (4): 758-773.

Froese, R., and D. Pauly, Eds. 2011. FishBase. World Wide Web electronic publication. www.fishbase.org, version.

Geraldi, N.R., S. P. Powers, K. L. Heck Jr., and J. Cebrian. 2009. Can habitat restoration be redundant? Response of mobile fishes and crustaceans to oyster reef restoration in marsh tidal creeks. Marine Ecology Progress Series 389: 171-180.

Grabowski, J.H., A.R. Hughes, D.L. Kimbro, and M.A. Dolan. 2005. How habitat setting influences restored oyster reef communities. Ecology 86 (7): 1926-1935.

Grabowski, J.H., R.D. Brumbaugh, R.F. Conrad, A.G. Keeler, J.J. Opaluch, C.H. Peterson, M.F. Piehler, S.P. Powers, and A.R. Smyth. 2012. Economic valuation of ecosystem services provided by oyster reefs. BioScience 62 (10): 900-909.

Grüss, A., K.A. Rose, J. Simons, C.H. Ainsworth, E.A. Babcock, D.D. Chagaris, K. De Mutsert, J. Froeschke, P. Himchak, I.C. Kaplan, H. O'Farrell, and M.J. Zetina Rejon. 2017. Recommendations on the use of ecosystem modeling for informing ecosystem-based fisheries management and restoration outcomes in the Gulf of Mexico. Marine and Coastal Fisheries 9 (1): 281-295.

Halpern, B.S., S. Walbridge, K.A. Selkoe, C.V. Kappel, F. Micheli, C. D'Agrosa, J.F. Bruno, K.S. Casey, C. Ebert, H.E. Fox, R. Fujita, D. Heinemann, H.S. Lenihan, E.M.P. Madin, M.T. Perry, E.R. Selig, M. Spalding, R. Steneck, and R. Watson. 2008. A global map of human impact on marine ecosystems. Science 319 (5865): 948-952.

Heck, K.L., Jr., G. Hays, and R.J. Orth. 2003. Critical evaluation of the nursery role hypothesis for seagrass meadows. Marine Ecology Progress Series 253: 123-136.

Hollweg, T.A., M.C. Christman, J. Cebrian, B.P. Wallace, S.L. Friedman, H.R. Ballestero, M.T. Huisenga, and K.G. Benson. 2020a. Metaanalysis of nekton utilization of coastal habitats in the northern Gulf of Mexico. Estuaries and Coasts. 43 (7): 1722-1745. https://doi. org/10.1007/s12237-019-00633-y.

Hollweg, T.A., M.C. Christman, J. Lipton, B.P. Wallace, M.T. Huisenga, D.R. Lane, and K.G. Benson. 2020b. Meta-analysis of nekton recovery following marsh restoration in the northern Gulf of Mexico. Estuaries and Coasts. 43 (7): 1746-1763. https://doi.org/10.1007/ s12237-019-00630-1.

Hutchinson, J., P.S.E. zu Ermgassen, and M. Spalding. 2015. The current state of knowledge on mangrove fishery values. Transactions of the American Fisheries Society 83: 3-15.

Kennish, M.J. 2001. Coastal salt marsh systems in the U.S.: A review of anthropogenic impacts. Journal of Coastal Research 17: 731-748.
Lai, Q.T., E.R. Irwin, and Y. Zhang. 2020. Quantifying harvestable fish and crustacean production and associated economic values provided by oyster reefs. Ocean \& Coastal Management 187: 105104.

Lederhouse, T., and J.S. Link. 2016. A proposal for fishery habitat conservation decision-support indicators. Coastal Management 44 (3): 209-222.

Lefcheck, J.S., B.B. Hughes, A.J. Johnson, B.W. Pfirrmann, D.B. Rasher, A.R. Smyth, B.L. Williams, M.W. Beck, and R.J. Orth. 2019. Are coastal habitats important nurseries? A meta-analysis. Conservation Letters 12: e12645.

Levin, P.S., and G.W. Stunz. 2005. Habitat triage for exploited fishes: Can we identify essential "Essential Fish Habitat?". Estuarine, Coastal and Shelf Science 64 (1): 70-78.

Lewis, M.A., R. Devereux, and P. Bourgeois. 2008. Seagrass distribution in the Pensacola Bay system, northwest Florida. Gulf and Caribbean Research 20: 21-28.

Lewis, M., Kirschenfeld, J.T. and Goodheart, T. (2016) Environmental Quality of the Pensacola Bay System: Retrospective Review for Future Resource Management and Rehabilitation. U.S. Environmental Protection Agency, Gulf Breeze, FL, EPA/600/R$16 / 169$.

Lorenzen, K. 2000. Allometry of natural mortality as a basis for assessing optimal release size in fish-stocking programmes. Canadian Journal of Fisheries and Aquatic Sciences 57 (12): 2374-2381.

Lotze, H.K., H.S. Lenihan, B.J. Bourque, R.H. Bradbury, R.G. Cooke, M.C. Kay, S.M. Kidwell, M.X. Kirby, C.H. Peterson, and J.B.C. Jackson. 2006. Depletion, degradation, and recovery potential of estuaries and coastal seas. Science 312 (5781): 1806-1809.

McSkimming, C., S.D. Connell, B.D. Russell, and J.E. Tanner. 2016. Habitat restoration: Early signs and extent of faunal recovery relative to seagrass recovery. Estuarine, Coastal and Shelf Science 171: 51-57.

Miltner, R.J., S.W. Ross, and M.H. Posey. 1995. Influence of food and predation on the depth distribution of juvenile spot (Leiostomus xanthurus) in tidal nurseries. Canadian Journal of Fisheries and Aquatic Sciences 52 (5): 971-982.

NOAA. 2019. National Oceanic and Atmospheric Administration, Office for Coastal Management. Coastal Change Analysis Program (CCAP) Regional Land Cover. Charleston, SC: NOAA Office for Coastal Management. Accessed Jan 2019 www.coast.noaa.gov/ htdata/raster1/landcover/bulkdownload/30m lc/.

Orth, R.J., T.J.B. Carruthers, W.C. Dennison, C.M. Duarte, J.W. Fourqurean, K.L. Heck Jr., A.R. Hughes, G.A. Kendrick, W.J. Kenworthy, S. Olyarnik, F.T. Short, M. Waycott, and S.L. Williams. 2006. A global crisis for seagrass ecosystems. BioScience 56 (12): 987-996.

Peters, K.M., and R.H. McMichael Jr. 1990. Early life history of the black drum Pogonias cromis (Pisces: Sciaenidae) in Tampa Bay, Florida. Northeast Gulf Science 11: 39-58.

Peterson, C.H., and R.N. Lipcius. 2003. Conceptual progress towards predicting quantitative ecosystem benefits of ecological restorations. Marine Ecology Progress Series 264: 297-307.

Peterson, C.H., J.H. Grabowski, and S.P. Powers. 2003. Estimated enhancement of fish production resulting from restoring oyster reef habitat: Quantitative valuation. Marine Ecology Progress Series 264: 249-264.

Pulich, W., Jr. 2007. Galveston Bay system. P. 17-28 in Handley, L., D. Altsman, and R. De May, eds., Seagrass status and trends in the northern Gulf of Mexico: 1940-2002. U.S. Geological Survey Scientific Investigations Report 2006-1587 and U.S. Environmental Protection Agency 855-R-04-003, $267 \mathrm{p}$.

Pulich, W.M., and W.A. White. 1991. Decline of submerged vegetation in the Galveston Bay system: Chronology and relationships to physical processes. Journal of Coastal Research 7: 1125-1138.

Rozas, L.P., and T.J. Minello. 1997. Estimating densities of small fishes and decapod crustaceans in shallow estuarine habitats: A review of sampling design with focus on gear selection. Estuaries 20 (1): 199-213. 
Rozas, L.P., and T.J. Minello. 1998. Nekton use of salt marsh, seagrass, and nonvegetated habitats in a south Texas (USA) estuary. Bulletin of Marine Science 63: 481-501.

Rozas, L.P., T.J. Minello, R.J. Zimmerman, and P. Caldwell. 2007. Nekton populations, long-term wetland loss, and the effect of recent habitat restoration in Galveston Bay, Texas, USA. Marine Ecology Progress Series 344: 119-130.

Schloesser, R.W., and M.C. Fabrizio. 2019. Nursery habitat quality assessed by the condition of juvenile fishes: Not all estuarine areas are equal. Estuaries and Coasts 42 (2): 548-566.

Sheaves, M., R. Baker, I. Nagelkerken, and R.M. Connolly. 2015. True value of estuarine and coastal nurseries for fish: Incorporating complexity and dynamics. Estuaries and Coasts 38 (2): 401-414.

Smyth, A.R., M.F. Piehler, and J.H. Grabowski. 2015. Habitat context influences nitrogen removal by restored oyster reefs. Journal of Applied Ecology 52 (3): 716-725.

Spalding, M. 2014. Mapping Ocean Wealth White Paper. The Nature Conservancy 14pp. Available at https://oceanwealth.org/ wpcontent/uploads/2021/04/MOW_White_Paper.pdf.

Spalding, M.D., A.L. McIvor, M.W. Beck, E.W. Koch, I. Möller, D.J. Reed, P. Rubinoff, T. Spencer, T.J. Tolhurst, T.V. Wamsley, B.K. van Wesenbeeck, E. Wolanski, and C.D. Woodroffe. 2014. Coastal ecosystems: A critical element of risk reduction. Conservation Letters 7 (3): 293-301.

Sundblad, G., U. Bergström, A. Sandström, and P. Eklöv. 2014. Nursery habitat availability limits adult stock sizes of predatory coastal fish. ICES Journal of Marine Science 71 (3): 672-680.

Thayer, G.W., H.F. Stuart, W.J. Kenworthy, J.F. Ustach, and A.B. Hall, eds. 1978. Habitat values of salt marshes, mangroves, and seagrasses for aquatic organisms. Wetland functions and values: the state of our understanding, 235-247. Minneapolis: American Water Resource Association.

Thorson, J.T., S.B. Munch, J.M. Cope, and J. Gao. 2017. Predicting life history parameters for all fishes worldwide. Ecol Applications 27 (8): 2262-2276.

Waycott, M., C.M. Duarte, T.J.B. Carruthers, R.J. Orth, W.C. Dennison, S. Olyarnik, A. Calladine, J.W. Fourqurean, K.L. Heck Jr., A.R. Hughes, G.A. Kendrick, W.J. Kenworthy, F.T. Short, and S.L. Williams. 2009. Accelerating loss of seagrasses across the globe threatens coastal ecosystems. Proceedings of the National Academy of Sciences 106 (30): 12377-12381.
White, W. A., T. A. Tremblay, E. G. Wermund, and L. R. Handley. 1993. Trends and status of wetland and aquatic habitats in the Galveston Bay system, Texas. The Galveston Bay National Estuary Program, Galveston, TX. Publication GBNEP-31.

Winemiller, K. 2015. Habitat use and diets of juvenile spot (Leiostomus xanthurus) and Atlantic croaker (Micropogonias undulatus) in a small estuary at Mad Island Marsh, Texas. Texas Journal of Science 64: 3-31.

Yarbro, L. A., and P. R. Carlson Jr., Eds. 2016. Seagrass integrated mapping and monitoring program: Mapping and monitoring report no. 2. Fish and Wildlife Research Institute Technical Report TR-17 version $2 . v i+281 \mathrm{p}$

Yoskowitz, D., C. Carollo, J.B. Pollack, C. Santos, and K. Welder. 2017. Integrated ecosystem services assessment: Valuation of changes due to sea level rise in Galveston Bay, Texas, USA. Integrated Environmental Assessment and Management 13 (2): 431-443.

Ziegler, S. L., R. Baker, S. C. Crosby, M. A. Barbeau, J. Cebrian, D. D. Colombano, R. M. Connolly, L. A. Deegan, B. L. Gilby, D. Mallick, C. W. Martin, J. A. Nelson, J. F. Reinhardt, C. Simenstad, N. J. Waltham, T. A. Worthington, and L. P. Rozas. 2021. Geographic variation in salt marsh structure and function for nekton: Finding commonality across multiple scales. Estuaries and Coasts. https:// doi.org/10.1007/s12237-020-00894-y.

Zu Ermgassen, P.S.E., M.D. Spalding, B. Blake, L.D. Coen, B. Dumbauld, S. Geiger, J.H. Grabowski, R. Grizzle, M. Luckenbach, K.A. McGraw, B. Rodney, J.L. Ruesink, S.P. Powers, and R.D. Brumbaugh. 2012. Historical ecology with real numbers: Past and present extent and biomass of an imperilled estuarine ecosystem. Proceedings of the Royal Society B 279 (1742): $3393-3400$.

zu Ermgassen, P.S.E., J.H. Grabowski, J.R. Gair, and S.P. Powers. 2016. Quantifying fish and mobile invertebrate production from a threatened nursery habitat. Journal of Applied Ecology 53 (2): 596-606.

zu Ermgassen, P.S.E., J. H. Grabowski, J. R. Gair, and S. P. Powers. 2018. Corrigendum to "Quantifying fish and mobile invertebrate production from a threatened nursery habitat". Journal of Applied Ecology 55(6): 3005-3009.

zu Ermgassen, P. S. E., R. Baker, M. W. Beck, K. Dodds, S. O. S. E. zu Ermgassen, D. Mallick, M. Taylor, and R. E. Turner. Ecosystem services: Delivering decision making for salt marshes. Estuaries and Coasts. This Issue.

\section{Affiliations}

\section{Philine S. E. zu Ermgassen ${ }^{1}$ (D) Bryan DeAngelis ${ }^{2}$ - Jonathan R. Gair ${ }^{3}$. Sophus zu Ermgassen ${ }^{4} \cdot$ Ronald Baker $^{5}$. Andre Daniels ${ }^{6}$. Timothy C. MacDonald ${ }^{7} \cdot$ Kara Meckley $^{8} \cdot$ Sean Powers ${ }^{5} \cdot$ Marta Ribera $^{9} \cdot$ Lawrence P. Rozas $^{10}$. Jonathan H. Grabowski ${ }^{11}$}

1 Changing Oceans Group, University of Edinburgh, Edinburgh, UK

2 The Nature Conservancy, URI Bay Campus, Narragansett, RI, USA

3 School of Mathematics, University of Edinburgh, Edinburgh, UK

4 Durrell Institute of Conservation and Ecology, School of Anthropology and Conservation, University of Kent, Canterbury, UK

5 Department of Marine Sciences, Dauphin Island Sea Lab, University of South Alabama, Mobile, AL, USA

6 USGS-Wetland and Aquatic Research Center, 3321 College Ave. CCR Building 1st Floor, Davie, FL, USA
7 Florida Fish and Wildlife Conservation Commission, Fish and Wildlife Research Institute, 100 Eighth Avenue SE, St. Petersburg, FL, USA

8 Office of Habitat Conservation, NOAA Fisheries Service, Silver Spring, MD, USA

9 The Nature Conservancy, Providence, RI, USA

10 NOAA Fisheries Service, 150 Cherokee Circle, Sunset, LA, USA

11 Marine Science Center, Northeastern University, Nahant, MA, USA 